\title{
Spatial Distribution of Marine Planktons off the Coast of Sitra, Kingdom of Bahrain
}

\author{
Belen T. Lumeran \\ AMA International University-Bahrain, Salmabad, Kingdom of Bahrain
}

\begin{abstract}
Determination of the spatial distribution of marine plankton off-coast of Sitra, Kingdom of Bahrain was conducted from August 2014-July 2015 to identify, categorize, and classify taxonomically the phyto-and-zooplankton. Population size was calculated based on abundance, density, and biomass from the collected water samples. Results showed 20 species of phytoplankton and 14 species of zooplankton. The phytoplankton includes 13 species which belong to Phylum Chrysophyta or diatoms, and seven species in Phylum Dinoflagellata or dinoflagellates. The 14 species of zooplankton were categorized to eight phyla_Protozoa, Cnidaria, Platyhelminthes, Rotifer, Annelida, Mollusca, Arthropoda, and Chordata. The identified species of phytoplankton and zooplankton vary in abundance, density, and biomass. Fragillariopsis and Navicula species were identified as the most abundant phytoplankton with higher density and biomass while Ceratium furca and Ceratium fusus of the zooplankton. Statistical analysis using ANOVA (Analysis of Variance) revealed significant differences at $p=0.05$ on abundance and density, however, insignificant difference in biomass. Based on dispersion index, the phytoplankton and zooplankton were found to be vertically distributed and aggregated mostly on the upper column where sunlight is abundant. Surface water temperature and salinity significantly affect the spatial distribution and population size of the identified marine plankton.
\end{abstract}

Keywords: spatial distribution, marine planktons, phytoplankton, zooplankton

It is a common observation that the earth surface is covered more of the ocean waters. The marine environment is considered the most productive ecosystem. The range of organisms makes up the community structure which varies from macroscopic to microscopic. There are microscopic organisms which are considered the natural inhabitants of the marine water. These organisms are called planktons which compose the grazing productivity of any marine ecosystem. Planktons are of two types, the phytoplankton and zooplanktons are well-distributed on the water surface following the route of current. Zooplanktons are considered the major primary consumers and predators in most aquatic ecosystems. These microscopic organisms are characteristically diverse (Litchman, Ohman, \& Kiorboe, 2013) which serve as food for many marine animals. The study of spatial structure is an important research in the field of ecology focusing on communities of organism in marine ecosystem. The spatial distribution of planktons determines the type of structure characteristic of a natural ecosystem (Chernova \& Primakov, 2011). Marine planktons inhabit the depths of the oceans in infinite numbers. This reveals the remarkable underwater world inhabited by microscopic organisms with biomass that is characteristically the

Corresponding author: Belen T. Lumeran, Ph.D., assistant professor, Department of Mathematics and Sciences, AMA International University-Bahrain, Salmabad, Kingdom of Bahrain; research fields: ecological monitoring, biodiversity and taxonomy, ecosystem and ecological studies, climate change, genetic engineering and biotechnology. 
same in the upper ocean (Woods Hole Oceanographic Institution, 2013). Both phytoplankton and zooplanktons drift with current in all marine environments. Although their abundance varies according to size, their occurrence in every liter of ocean water is remarkable with 95\% biomass (Abida et al., 2013). Marine planktons exert influence on the ecosystems of the world and on the marine environments as well (Ayre, 2013).

The marine water of the Kingdom of Bahrain is richly endowed with resources in determining community structure. Specifically, the sprawling water three to four miles off the coast of the northeastern part of Sitra serves as the habitat of microscopic, surface-dwelling plankton. The conservation of marine communities is integrated to the ecological web of marine life. The local abundance and spatial distribution of both phytoplankton and zooplanktons are attributed to various factors. Considering the environmental factors, water temperature and salinity were monitored throughout the study. The effects of these factors may directly or indirectly determine the spatial distribution and population size of the identified planktons in the study site.

\section{Objectives of the Study}

This research undertaking was conducted to determine the spatial distribution of planktons off the coast of Sitra, Kingdom of Bahrain. Specifically, this study was conducted:

(1) To determine and identify the planktons off the coast of Sitra, Kingdom of Bahrain;

(2) To categorize the planktons as phytoplankton and zooplanktons and classify taxonomically;

(3) To calculate the population size of the identified planktons based on abundance, density, and total biomass using settled volume method;

(4) To find out significance differences in the calculated population size of the identified planktons based on the parameters;

(5) To determine dispersion index of the identified planktons;

(6) To monitor the surface water temperature and salinity, and their effects on the spatial distribution and population size of the identified planktons.

\section{Literature Review}

\section{Marine Planktons, Characteristics, and Spatial Distribution}

Planktons are small and diverse organisms that live in water column (Petitgas et al., 2006) of the marine water and other bodies of water. This includes variety of drifting animals, protist, archae, algae, or bacteria in the pelagic zone of oceans and seas. Variation in terms of local abundance is highly influenced by sunlight and availability of nutrients. Characteristically, local abundance varies seasonally, horizontally, and vertically. The effect of population size variation is on primary production which is usually concentrated on the water surface. Geographically and seasonally, this is attributed to abundant sunlight. These organisms as defined by their ecologic niche are light-dependent, hence population size varies from region to region in the world oceans. Planktons are categorized into three main functional groups. The phytoplankton referred to as the plants of the sea that live near water surface with sufficient sunlight for photosynthesis. This group includes cyanobacteria, diatoms, and dinoflagellates. The zooplanktons are small animals like crustaceans, small protozoan, or metazoans that feed on other plankton. Included in this group are some eggs and larvae of large animals like fish crustaceans and annelids.

The interactions of the various factors such as the organism's behavior and physical oceanographic processes determine the spatial distribution of organisms in the ocean. 
Generally, planktons display a broad range of behavioral pattern that determines their vertical and horizontal distribution in the ocean. The organism's response to the physical environment influences planktonic aggregation. This then causes a direct impact on the function of marine ecosystems (McManus \& Woodson, 2012). The variation in the dynamics of the ocean is attributed to multiple factors. Vertical migration as a global phenomenon is a characteristic of the world ocean to describe the synchronized movement of both phytoplankton and zooplankton. This phenomenon balances the need for feeding on the surface where food is abundant. The patterns of migration are also directly controlled by solar light (Berge et al., 2014). Individual organisms and population experience total environment variability such as upper water column of oceans and seasonal cycles (Ji, Edwards, Mackas, Runge, \& Thomas, 2010). The spatial distribution varies in individual plankton taxa based on the standardized number in $\mathrm{m}^{3}$ from each water sample (Heildelberg, O'Neil, Bythell, \& Sebens, 2010). Among the zooplanktons, copepods are numerically abundant in terms of number and biomass (Heildelberg et al., 2010; Jaspers, Nielsen, Carstensen, Hopcroft, \& Moller, 2009). The spatial variability of plankton's biomass is influenced by its size (Mompean et al., 2013; Flynn et al., 2013). The spatial distribution of organisms in the ocean is determined by interactions between the behavior of the organism and physical structure and process of the ocean water. The physical structures and processes are important driving force for the distribution and dispersal of the organism. This is attributed to the swimming and behavioral capabilities of individual species (Aleksandrov, Zhigalova, \& Zezera, 2009). There is unlimited horizontal distribution of plankton. However, their vertical extent is constrained by the sunlit layer of the sea (Bagheri, Mansor, Turkoglu, Makaremi, \& Babaei, 2012).

\section{Research Model}

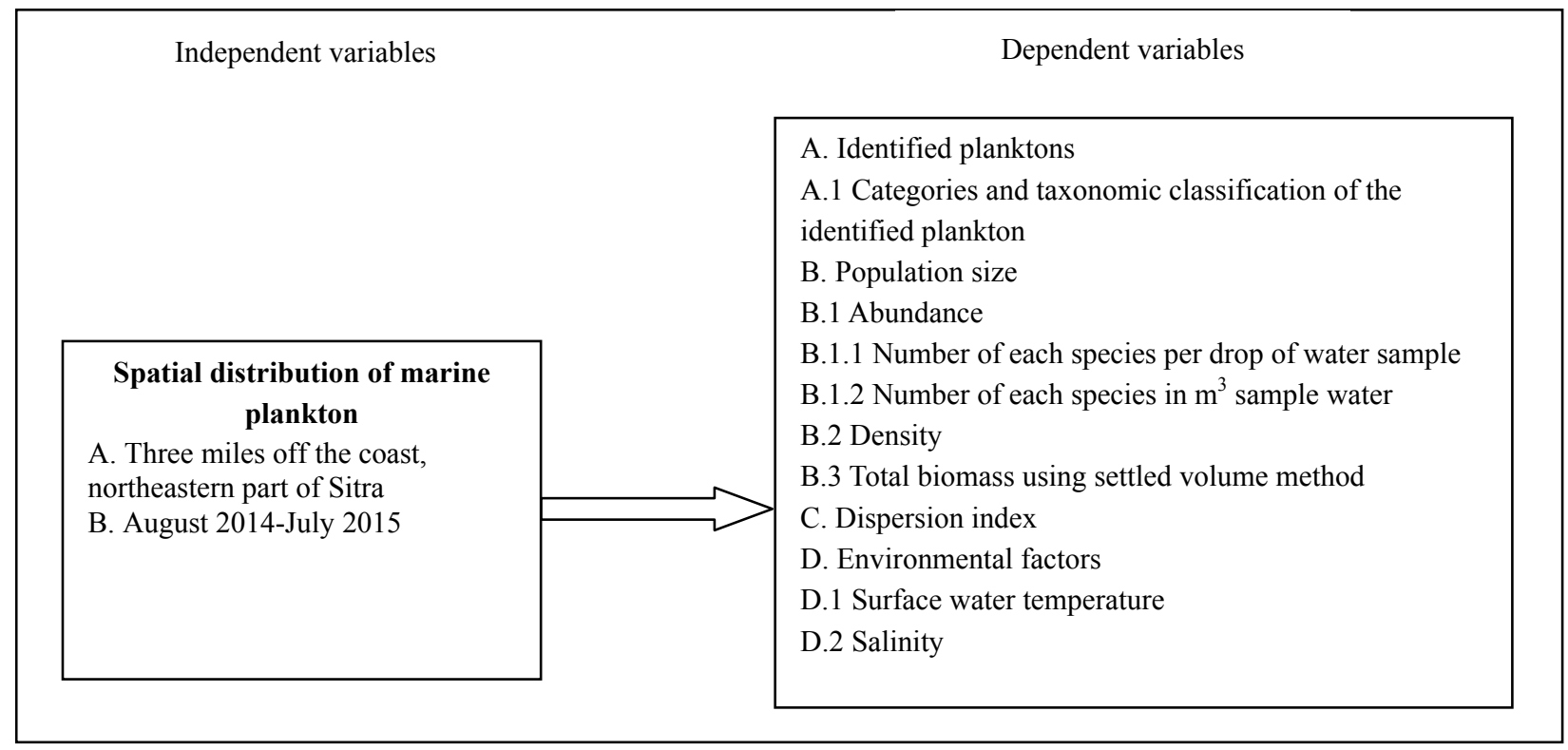

Figure 1. Research model.

Above is the research model of the study. The interactions of various factors determine the spatial distribution of organisms in the ocean which causes an influence in planktonic aggregation (McManus \& Woodson, 2012). Figure 1 shows the research model of the study showing the relationship of the different variables. The spatial distribution of marine plankton three miles off-coast in the northeastern part of Sitra from 
August 2014 to July 2015 is the independent variable. The dependent variables are the identified planktons which were categorized and classified taxonomically. The population size was determined based on abundance as indicated by the number of each species per drop of water sample and number of each species per $\mathrm{m}^{3}$ of water sample, density, and total biomass using settled volume method. Dispersion index was also calculated for every change in water column of distance sampling in miles. Important environmental factors like surface water temperature and salinity were monitored, which may exert direct or indirect effect on the spatial distribution and population size of plankton for the duration of the study.

\section{Data Analysis}

Table 1

Identified Planktons Off-coast of Northeastern Part of Sitra, Kingdom of Bahrain, August 2014-July 2015

\begin{tabular}{|c|c|c|c|}
\hline \multicolumn{2}{|c|}{ Phytoplankton } & \multicolumn{2}{|l|}{ Zooplankton } \\
\hline \multicolumn{2}{|c|}{ Phylum chrysophyta or diatoms } & \multicolumn{2}{|c|}{ Phylum protozoa } \\
\hline Genus & Species & Genus & Species \\
\hline Biddulphia & Aurita & 1. Globigernia & Bulloides \\
\hline Chaetoceros & $s p$. & 2. Radiolarian & $s p$. \\
\hline Coscinodiscus & $s p$. & \multicolumn{2}{|l|}{ Phylum cnidaria } \\
\hline Ditylum & Brightwellii & 1. Actinula larvae & $s p$ \\
\hline Fragillariopsis & $s p$. & \multicolumn{2}{|c|}{ Phylum platyhelminthes } \\
\hline Lauderia & Annulata & 1. Platyhelminthes & $s p$ \\
\hline Lioloma & Pacificum & \multicolumn{2}{|l|}{ Phylum rotifera } \\
\hline Navicula & $s p$. & 1. Branchionus & Plicatitlis \\
\hline Proboscia & Alata & 2. Rotifer & $s p$. \\
\hline Pseudo-nitzschia & Australis & \multicolumn{2}{|c|}{ Phylum annelida } \\
\hline Rhizosolenia & $s p$. & 1. Early trochophore polychaete larvae & $s p$. \\
\hline Thalassiosira & Punctigera & \multicolumn{2}{|l|}{ Phylum mollusca } \\
\hline Thalassiosira & $s p$. & 1. Bivalve veliger larvae & $s p$. \\
\hline \multicolumn{2}{|c|}{ Phylum dinoflagellata or dinoflagellates } & \multicolumn{2}{|c|}{ Phylum arthropoda } \\
\hline Alexandrium & $s p$. & 1. Calanoid copepod & $s p$. \\
\hline Ceratium & Furca & 2. Harpacticoid copepod & $s p$. \\
\hline Ceratium & Lineatum & 3. Crustacean cypris larvae & sp. \\
\hline Ceratium & Fusus & 4. Crustacean nauplius larvae & $s p$. \\
\hline Peridium & $s p$. & \multicolumn{2}{|c|}{ Phylum chordata } \\
\hline Pololampasa & Palmipes & 1. Fritillaria & $s p$. \\
\hline Prorocentrum & Micans & 2. Oikopleura & $s p$. \\
\hline
\end{tabular}

The phytoplankton identified three miles off-coast of Sitra, Kingdom of Bahrain is composed of two major phyla, Phylum Chrysophyta or known by the common name diatoms, with 13 species and Phylum Dinoflagellata or dinoflagellates with seven species. The dinoflagellates are mostly Ceratium species. The zooplankton with eight phyla-Protozoa, Cnidaria, Platyhelminthes, Rotifera, Annelida, Mollusca, Arthropoda, and Chordata composed mostly of larvae, some identified and unidentified species. Of the eight phyla, Phylum Arthropoda comprised the most number of species, mostly crustacean larvae and copepods. Although the phyla composition of zooplankton is more than the phytoplankton, however, in terms of species composition, phytoplankton comprised the most number. Characteristically, the local abundance of plankton varies vertically. 
Table 2

Population Size of the Identified Plankton

\begin{tabular}{|c|c|c|c|c|c|}
\hline \multirow{3}{*}{$\begin{array}{l}\text { Identified plankton } \\
\text { I. Phytoplankton }\end{array}$} & \multicolumn{5}{|c|}{ Population size } \\
\hline & \multicolumn{3}{|c|}{ Abundance } & \multirow{2}{*}{$\begin{array}{l}\text { Density } \\
\text { (number } / \mathrm{m}^{3} \text { ) }\end{array}$} & \multirow{2}{*}{$\begin{array}{l}\text { Total } \\
\text { biomass } \\
\left(\mathrm{mL} / \mathrm{m}^{3}\right)\end{array}$} \\
\hline & $\begin{array}{l}\text { Average number } \\
\text { per drop sampled }\end{array}$ & $\begin{array}{l}\text { Number per } \mathrm{m}^{3} \\
\text { sampled water }\end{array}$ & $\begin{array}{l}\text { Total } \\
\text { abundance }\end{array}$ & & \\
\hline \multicolumn{6}{|l|}{ A. Phylum chrysophyta (diatoms) } \\
\hline Biddulphia aurita & 0.05 & 562 & 11 & 25 & 0.1 \\
\hline Chaetoceros sp. & 0.64 & 7,200 & 144 & 320 & 0.128 \\
\hline Coscinodiscus sp. & 0.11 & 1,238 & 25 & 55 & 0.22 \\
\hline Ditylum brightwellii & 0.11 & 1,238 & 25 & 55 & 0.22 \\
\hline Fragillariopsis $s p$ & 0.80 & 9,000 & 180 & 400 & 0.16 \\
\hline Lauderia annulata & 0.43 & 4,838 & 97 & 215 & 0.86 \\
\hline Lioloma pacificum & 0.21 & 2,362 & 47 & 105 & 0.42 \\
\hline Navicula sp. & 0.80 & 9,000 & 180 & 400 & 0.16 \\
\hline Proboscia alata & 0.37 & 4,162 & 83 & 185 & 0.74 \\
\hline Pseudo-nitzschia australis & 0.27 & 3,038 & 61 & 135 & 0.54 \\
\hline Rhizosolenia sp. & 0.11 & 1,238 & 25 & 55 & 0.22 \\
\hline Thalassiosira punctigera & 0.59 & 6,638 & 133 & 295 & 0.118 \\
\hline Thalassiosira sp. & 0.11 & 1,238 & 25 & 55 & 0.22 \\
\hline \multicolumn{6}{|l|}{ B. Phylum dinoflagellata (dinoflagellates) } \\
\hline Alexandrium $s p$. & 0.11 & 1,638 & 25 & 55 & 0.22 \\
\hline Ceratium furca & 1.65 & 18,562 & 371 & 825 & 0.33 \\
\hline Ceratium lineatum & 0.05 & 562 & 11 & 25 & 0.1 \\
\hline Ceratium fusus & 1.12 & 12,600 & 252 & 560 & 0.224 \\
\hline Peridium sp. & 0.05 & 562 & 11 & 25 & 0.1 \\
\hline Pololampasa palmipes & 0.05 & 562 & 11 & 25 & 0.1 \\
\hline Prorocentrum micans & 0.11 & 1,638 & 25 & 55 & 0.22 \\
\hline \multicolumn{6}{|l|}{ II. Zooplankton } \\
\hline \multicolumn{6}{|l|}{ A. Phylum protozoa } \\
\hline Globigernia bulloides & 0.05 & 562 & 11 & 25 & 0.1 \\
\hline Radiolarian $s p$ & 0.21 & 2,362 & 47 & 105 & 0.42 \\
\hline \multicolumn{6}{|l|}{ B. Phylum cnidaria } \\
\hline Actinula larvae $s p$ & 0.05 & 562 & 11 & 25 & 0.1 \\
\hline \multicolumn{6}{|l|}{ C. Phylum platyhelminthes } \\
\hline Platyhelminthes $s p$ & 0.05 & 562 & 11 & 25 & 0.1 \\
\hline \multicolumn{6}{|l|}{ D. Phylum rotifera } \\
\hline Branchionus plicatitlis & 0.05 & 562 & 11 & 25 & 0.1 \\
\hline Rotifer $s p$ & 0.05 & 562 & 11 & 25 & 0.1 \\
\hline \multicolumn{6}{|l|}{ E. Phylum annelida } \\
\hline Early trochophore polychaete larvae $s p$. & 0.05 & 562 & 11 & 25 & 0.1 \\
\hline \multicolumn{6}{|l|}{ F. Phylum mollusca } \\
\hline Bivalve veliger larvae $s p$ & 0.05 & 562 & 11 & 25 & 0.1 \\
\hline \multicolumn{6}{|l|}{ G. Phylum arthropoda } \\
\hline Calanoid copepod $s p$ & 0.05 & 562 & 11 & 25 & 0.1 \\
\hline Harpacticoid copepod $s p$ & 0.21 & 2,362 & 47 & 105 & 0.42 \\
\hline Crustacean cypris larvae $s p$. & 0.59 & 6,638 & 133 & 295 & 0.118 \\
\hline Crustacean nauplius larvae $s p$. & 0.59 & 6,638 & 133 & 295 & 0.118 \\
\hline \multicolumn{6}{|l|}{ H. Phylum chordata } \\
\hline Fritillaria sp. & 0.05 & 562 & 11 & 25 & 0.1 \\
\hline Oikopleura sp. & 0.05 & 562 & 11 & 25 & 0.1 \\
\hline
\end{tabular}


The population size of the identified plankton is determined based on abundance, density, and biomass, which is shown in Table 2. The index for abundance is the average number of species per drop sampled and the number of species per $\mathrm{m}^{3}$ sampled sea water. Results revealed that of the phytoplankton, the diatoms Fragillariopsis and Navicula sp. had the highest average number per drop, 0.80 , followed by Thalassiosira puntigera (0.59), and Lauderia annulata (0.43), respectively. Similarly, the same species incurred the highest number per $\mathrm{m}^{3}$ of sea water-9,000,6,638, and 4,883 based on species occurrence and the most abundant species as well. Whereas, Ceratium furca $\left(\# / \mathrm{drop} / \mathrm{m}^{3}=1.65 / 18,562\right)$, and Ceratium fusus $\left(\# / \mathrm{drop} / \mathrm{m}^{3}=\right.$ $1.12 / 12,600)$ are the most abundant of the dinoflagellates. Results also depicted the highest density of the same species.

The zooplankton although composed of many phyla (see Table 1), the radiolarian sp. of Phylum Protozoa had the highest values for the number per drop/per $\mathrm{m}^{3}, 0.21 / 2,363$, while crustacean larvae cypris and nauplius $s p$. followed with $0.59 / 6,638$ and $0.59 / 6,638$, respectively. The same species are considered the most abundant with the highest density and biomass as well.

Table 3

Results of Analysis of Variance (ANOVA) on (a) Abundance, (b) Density, and (c) Biomass of the Identified Planktons (a) On abundance

\begin{tabular}{llllll}
\hline & SS & df & MS & F-value & $p$-value \\
\hline Between groups & $25,723.334$ & 2 & $12,861.667$ & 199.579 & $0.000^{*}$ \\
Within groups & $1,997.762$ & 31 & 64.444 & & \\
Total & $27,721.096$ & 33 & & & \\
\hline
\end{tabular}

Note. ${ }^{*}$ the mean difference is significant at 0.05 level.

(b) On density

\begin{tabular}{llllll}
\hline & SS & df & MS & F-value & $p$-value \\
\hline Between groups & $96,815.147$ & 2 & $48,407.573$ & 352.382 & $0.000^{*}$ \\
Within groups & $4,258.551$ & 31 & 137.373 & & \\
Total & $101,073.98$ & 33 & & & \\
\hline
\end{tabular}

Note. ${ }^{*}$ the mean difference is significant at 0.05 level.

(c) On biomass

\begin{tabular}{llllll}
\hline & SS & df & MS & F-value & $p$-value \\
\hline Between groups & 0.200 & 2 & 0.100 & 0.452 & $0.639^{\mathrm{NS}}$ \\
Within groups & 6.826 & 31 & 0.220 & & \\
Total & 7.026 & 33 & & & \\
\hline
\end{tabular}

Note. ${ }^{\text {NS }}$ means not significant at 0.05 level.

Statistical analysis using ANOVA (Analysis of Variance) [see Table 3 (a, b)] depicted significant differences at 0.05 level in terms of abundance and density of the identified planktons. The $p$-values $=0.000<$ 0.05 for abundance and density, hence the mean difference is significant at 0.05 level. Using variance-to-mean ratio (VMR) showed a dispersion index, $\mathrm{I}_{\mathrm{w}}=161.24$ for the phytoplankton while 876.156 for the zooplankton, which means they are vertically distributed and aggregated mostly on the upper lighted column of the water.

Statistical analysis using ANOVA showed insignificant difference in temperature and salinity at varying sampling month at 0.05 level with $p$-value of $0.083>0.05$. 
Table 4

Results of Analysis of Variance (ANOVA) on Temperature and Salinity at Varying Months

\begin{tabular}{llllll}
\hline & SS & df & MS & F-value & $p$-value \\
\hline Between groups & 107.104 & 1 & 107.104 & 3.301 & $0.083^{\text {NS }}$ \\
Within groups & 713.908 & 22 & 32.450 & & \\
Total & 821.012 & 23 & & & \\
\hline
\end{tabular}

Note. ${ }^{\text {NS }}$ means insignificant at 0.05 level.

Table 5

Results of Analysis of Variance (ANOVA) of Temperature-Salinity Effect on (a) Abundance, (b) Density, and (c) Biomass of the Identified Planktons

(a) On abundance

\begin{tabular}{llllll}
\hline & SS & df & MS & F-value & $p$-value \\
\hline Between groups & $40,893.392$ & 4 & $10,223.348$ & 199.817 & $0.000^{*}$ \\
Within groups & $2,711.670$ & 53 & 51.164 & & \\
Total & 821.012 & 57 & & & \\
\hline
\end{tabular}

Note. ${ }^{*}$ the mean difference is significant at 0.05 level.

(b) On density

\begin{tabular}{llllll}
\hline & SS & df & MS & F-value & $p$-value \\
\hline Between groups & $254,741.678$ & 4 & $63,685.420$ & 678.864 & $0.000^{*}$ \\
Within groups & $4,972.459$ & 53 & 93.820 & & \\
Total & $259,714.137$ & 57 & & & \\
\hline
\end{tabular}

Note. ${ }^{*}$ the mean difference is significant at 0.05 level.

(c) On biomass

\begin{tabular}{llllll}
\hline & SS & df & MS & F-value & $p$-value \\
\hline Between groups & $14,725.104$ & 4 & $3,681.276$ & 270.707 & $0.000^{*}$ \\
Within groups & 720.734 & 53 & 13.549 & & \\
Total & $15,445.837$ & 57 & & & \\
\hline
\end{tabular}

Note. ${ }^{*}$ the mean difference is significant at 0.05 level.

Results of ANOVA in Table $5(\mathrm{a}, \mathrm{b}, \mathrm{c})$ depicted significant temperature-salinity effect on the abundance, density, and biomass with $p$-values $=0.000<0.05$.

\section{Discussions}

Table 1 presents the identified plankton off-coast in northeastern part of Sitra, Kingdom of Bahrain. Results showed two categories of plankton, the phytoplankton and the zooplankton classified taxonomically using references (Somshekar, Dhargalkar, \& Karlekan, 2004; Perry, 2003; Hauser \& Dudiak, 1981). The phytoplankton is usually found on surface water (Petitgas et al., 2006) with sufficient sunlight for photosynthesis (McManus \& Woodson, 2012). This group includes the diatoms and dinoflagellates as shown in the results of this study with 13 species of diatoms and seven species of dinoflagellates. Ecologically, phytoplankton is considered important producer in the marine ecosystem (Perry, 2003).

In Table 2, population size of the identified plankton is determined by total abundance, density, and biomass. The effect of population size is on primary production (Petitgas et al., 2006) since the phytoplankton 
is considered the producer (McManus \& Woodson, 2012) of the marine ecosystems which inhabit the illuminated (Aleksandrov et al., 2009) part of the sea water. Dinoflagellates are also considered common coastal plankton (Somshekar et al., 2004). The zooplankton includes many crustacean larvae (Petitgas et al., 2006) which become food for other plankton (McManus \& Woodson, 2012). The spatial distribution of planktons is influenced by the physical characteristic of the ocean water (Aleksandrov et al., 2009). Vertical migration is also described as a synchronized movement of both phytoplankton and the zooplankton (Petitgas et al., 2006). The pattern of migration is directly controlled by solar light (Berge et al., 2014). Individual organisms and population experience environmental variability due to changes in water column and seasonal cycles (Ji et al., 2010). Results showed spatial variability in abundance, density, and biomass. The spatial variability of plankton's biomass (Mompean et al., 2013) is influenced by its size (Flynn et al., 2013). Different studies on plankton (Aleksandrov et al., 2009; Bagheri et al., 2012; Dvoretsky, Venger, Makarevich, \& Moiseev, 2012; Caric, Jasprica, Krsinic, Vilibic, \& Batistic, 2012; Selifonova, 2012; Motylkova \& Konovalova, 2010) depicted biomass, abundance, and density determination as these factors are also correlated to oceanographic processes and events (Dvoretsky et al., 2012), temperature (Radchenko, Loboda, Figurkin, Gorbatenko, \& Ovsyannikov, 2010), and behavioral patterns (Berge et al., 2014) of the organisms.

Results of statistical analysis using ANOVA in Table 3 imply that the number of each species varies significantly as each species occurs in every drop and $\mathrm{m}^{3}$ of sea water. The use of settled volume method (Perry, 2003; Hauser \& Dudiak, 1981) may not be able to measure accurately the plankton biomass. This may be attributed to the time required for the plankton to settle although there is no set standard time (Hauser \& Dudiak, 1981).

The index of dispersion (ID) is used to describe the spatial distribution of planktons following vertical zoning, $\mathrm{I}_{\mathrm{w}}=\sigma^{2} / \mathrm{m}$. Although sampling is not of wide coverage (limited only to three miles), measurement of dispersion may not be necessarily calculated (Chernova \& Primakov, 2011). Results further show that both the phytoplankton and the zooplankton are over dispersed characterized by negative binomial distribution. This result implies that most of the plankton aggregate on the upper strata of the vertical zone, the most illuminated part of the surface water (Somshekar et al., 2004).

On temperature and salinity interaction at varying months (see Table 4), results imply that temperature and salinity are constant in the entire duration of the sampling. Accordingly, planktons are diverse organisms that live in water column (Petitgas et al., 2006) and defined by their ecologic niche (McManus \& Woodson, 2012), and are light-dependent (Berge et al., 2014) which inhabit the illuminated $200 \mathrm{~m}$ (Somshekar et al., 2004) of the surface water. The vertical distribution of the planktons is influenced by the constant temperature and salinity (see Table 4) of the sea water during the period of study. Results in Table 5 can be further interpreted that temperature ranged in $28-33{ }^{\circ} \mathrm{C}$ and salinity ranged in 36-38.8 $\% 00$ are considered favorable environmental condition of the water column for the movement of planktons following vertical path (McManus \& Woodson, 2012) related to hydrographic (Caric et al., 2012).

\section{Conclusions}

Based on the findings of this particular study, the following conclusions are hereby formulated:

(1) Plankton such as phytoplankton and zooplankton are found off-coast of Sitra, Kingdom of Bahrain;

(2) The identified species of plankton are categorized as phytoplankton and zooplankton which belong to different phyla composed of different species; 
(3) The population size of the identified phytoplankton and zooplankton varies in abundance, density, and biomass;

(4) The abundance and density of phytoplankton and zooplankton vary significantly per drop $/ \mathrm{m}^{3}$ of sea water samples but not in biomass;

(5) Phytoplankton and zooplankton are vertically distributed and aggregation is mostly on the upper water column where sunlight is abundant;

(6) A surface water temperature of $30.40{ }^{\circ} \mathrm{C}$ corresponding to a salinity of 34.57 parts per thousand is favorable environmental conditions for the spatial distribution of the identified phyto-zooplankton three miles off-coast of Sitra, Kingdom of Bahrain.

\section{References}

Abida, H., Ruchard, S., Rios, L., Humean, A., Probert, I., De Vargas, C., ... Bowler, C. (2013). Bioprospecting marine plankton. Mar Drugs, 11(11), 4594-4611.

Aleksandrov, S. V., Zhigalova, N. N., \& Zezera, A. S. (2009). Long-Term dynamics of zooplankton in the southern Baltic Sea. Russian Journal of Marine Biology, 35(4), 296-304.

Ayre, J. (2013). Underwater universe uncovered with completion of first global atlas of marine plankton. Retrieved from http://planetsave.com/2013/07/21/underwater-universe-uncovered-with-completion-of-first-global-atlas-of-marine-plankton/

Bagheri, S., Mansor, M., Turkoglu, M., Makaremi, M., \& Babaei, H. (2012). Temporal distribution of phytoplankton in the south-western Caspian Sea during 2009-2010: A comparison with previous surveys. Journal of the Marine Biological Association of the United Kingdom, 92(6), 1243-1255.

Berge, J., Cottier, F., Varpe, O., Renaud, P. E., Falk-Petersen, S., Kwasniewski, S., ... Majaneva, S. (2014). Arctic complexity: A case study on diel vertical migration of zooplankton. J Plankton Res, 36(5), 1279-1297.

Caric, M., Jasprica, N., Krsinic, F., Vilibic, I., \& Batistic, M. (2012). Hydrography, nutrients, and plankton along the longitudinal section of the Ombla Estuary (south-eastern Adriatic). Journal of the Marine Biological Association of the United Kingdom, 92(06), 1227-1242.

Chernova, E. N., \& Primakov, E. M. (2011). Distribution of zooplankton in the estuary of Keretskaya Guba (White Sea). Russian Journal of Marine Biology, 37(2), 104-110.

Dvoretsky, V. G., Venger, M. P., Makarevich, P. R., \& Moiseev, D. V. (2012). Summer bacterio- and zooplankton in the coastal waters of Svalbard. Russian Journal of Marine Biology, 38(1), 91-95.

Flynn, K. J., Stoecker, D. K., Mitra, A., Raven, J. A., Glibert, P. M., Hansen, P. J., ... Burkholder, J. M. (2013). Misuse of the phytoplankton-zooplankton dichotomy: The need to assign organisms as mixotrophs within plankton functional types. $J$ Plankton Res, 35(1), 3-11.

Hauser, W. J., \& Dudiak, N. (1981). Manual for environmental and zooplankton studies. Division of fisheries and rehabilitation enhancement and development. Anchorage, Alaska.

Heidelberg, K. B., O’Neil, K. L., Bythell, J. C., \& Sebens, K. P. (2010). Vertical distribution and diel patterns of zooplankton abundance and biomass at Conch Reef, Florida Keys (USA). J Plankton Res, 32(1), 75-91.

Jaspers, C., Nielsen, T. G., Carstensen, J., Hopcroft, R. R., \& Moller, E. F. (2009). Metazooplankton distribution across the Southern Indian Ocean with emphasis on the role of Larvaceans. J Plankton Res, 31(5), 525-540.

Ji, R., Edwards, M. R., Mackas, D. L., Runge, J. A., \& Thomas, A. C. (2010). Marine plankton phenology and life history in a changing climate: Current research and future directions. J Plankton Res, 32(10), 1355-1368.

Litchman, E., Ohman, M. D., \& Kiorboe, T. (2013). Trait-Based approaches to zooplankton communities. J Plankton Res, 35(3), 473-484.

McManus, M. A., \& Woodson, C. B. (2012). Plankton distribution and ocean dispersal. J Exp Biol, 215, 1008-1016.

Mompean, C., Bode, A., Benitez-Barrios, V. M., Dominguez-Yanes, J. F., Escanez, J., \& Fraile-Nuez, E. (2013). Spatial patterns of plankton biomass and stable isotopes reflect the influence of the nitrogen-fixer Trichodesmium along the subtropical North Atlanta. J Plankton Res, 35(3), 513-525.

Motylkova, I. V., \& Konovalova, N. V. (2010). Seasonal dynamics of phytoplankton in a lagoon-type lake Izmenchivoye (Southeast Sakhalin). Russian Journal of Marine Biology, 36(2), 86-92. 
Perry, R. (2003). Guide to marine plankton of South California (3rd ed.). UCLA Marine Science Center.

Petitgas, P., Masse, J., Bourriau, P., Beillois, P., Bergeron, J. P., Delmas, D., ... Santos, M. (2006). Hydro-plankton characteristics and their relationship with sardine and anchovy distributions on the French shelf of the Bay of Biscay. Scientia Marina, 70(S1), 161-172.

Radchenko, V. I., Loboda, S. V., Figurkin, A. L., Gorbatenko, K. M., \& Ovsyannikov, E. E. (2010). Environmental conditions and compositions of plankton and nekton in the epipelagic zone of the northwestern Pacific Ocean in summer 2009, the year of the largest spawning migration of pink and Chum Salmon. Russian Journal of Marine Biology, 36(7), 473-488.

Selifonova, Zh. P. (2012). Taxonomic composition and seasonal dynamics of the meroplankton of the coastal zone of the northeastern Black Sea. Russian Journal of Marine Biology, 38(1), 1-9.

Somshekar, D., Dhargalkar, V. K., \& Karlekan, D. (2004). Phytoplankton identification manual (1st ed.). National Institute of Oceanography.

Woods Hole Oceanographic Institution. (2013). First global atlas of marine plankton reveals remarkable underwater world. Retrieved from http://www.whoi.edu/news-release/planktonatlas 